\title{
Protective Effect of PPAR $\gamma$ Agonists on Cerebellar Tissues Oxidative Damage in Hypothyroid Rats
}

\author{
Yousef Baghcheghi, ${ }^{1}$ Farimah Beheshti, ${ }^{2}$ Hossein Salmani, ${ }^{3}$ \\ Mohammad Soukhtanloo, ${ }^{4}$ and Mahmoud Hosseini ${ }^{2}$ \\ ${ }^{1}$ Student Research Committee, Department of Physiology, Faculty of Medicine, \\ Mashhad University of Medical Sciences, Mashhad, Iran \\ ${ }^{2}$ Neurocognitive Research Center, Faculty of Medicine, Mashhad University of Medical Sciences, Mashhad, Iran \\ ${ }^{3}$ Neurogenic Inflammation Research Center, Faculty of Medicine, Mashhad University of Medical Sciences, Mashhad, Iran \\ ${ }^{4}$ Department of Biochemistry, Faculty of Medicine, Mashhad University of Medical Sciences, Mashhad, Iran
}

Correspondence should be addressed to Mahmoud Hosseini; hosseinim@mums.ac.ir

Received 23 August 2016; Revised 6 November 2016; Accepted 30 November 2016

Academic Editor: Changiz Geula

Copyright (C) 2016 Yousef Baghcheghi et al. This is an open access article distributed under the Creative Commons Attribution License, which permits unrestricted use, distribution, and reproduction in any medium, provided the original work is properly cited.

\begin{abstract}
The aim of the current study was to investigate the effects of peroxisome proliferator-activated receptor gamma (PPAR $\gamma)$ agonists on cerebellar tissues oxidative damage in hypothyroid rats. The animals included seven groups: group I (control), the animals received drinking water; group II, the animals received $0.05 \%$ propylthiouracil (PTU) in drinking water; besides PTU, the animals in groups III, IV, V, VI, and VII, were injected with $20 \mathrm{mg} / \mathrm{kg}$ vitamin E (Vit E), 10 or $20 \mathrm{mg} / \mathrm{kg}$ pioglitazone, and 2 or $4 \mathrm{mg} / \mathrm{kg}$ rosiglitazone, respectively. The animals were deeply anesthetized and the cerebellar tissues were removed for biochemical measurements. PTU administration reduced thiol content, superoxide dismutase (SOD), and catalase (CAT) activities in the cerebellar tissues while increasing malondialdehyde (MDA) and nitric oxide (NO) metabolites. Vit E, pioglitazone, and rosiglitazone increased thiol, SOD, and CAT in the cerebellar tissues while reducing MDA and NO metabolites. The results of present study showed that, similar to Vit E, both rosiglitazone and pioglitazone as PPAR $\gamma$ agonists exerted protective effects against cerebellar tissues oxidative damage in hypothyroid rats.
\end{abstract}

\section{Introduction}

The brain is enriched with polyunsaturated fatty acids (PUFA) which make them vulnerable to attack by reactive oxygen species (ROS). ROS are by-products of normal metabolism in all aerobic cells. Most of the oxygen consumed by the cells is tetravalently reduced to water during mitochondrial respiration. Conversely, incomplete reduction of $2-3 \%$ of oxygen forms superoxide anion radical $\left(\mathrm{O}_{2}^{--}\right)$, which is highly reactive and can indiscriminately attack all cellular biomolecules in their vicinity. A sensitive balance exists between ROS production and the antioxidant defenses that protect the cells in vivo. All the same, aerobes are endowed with an orchestra of antioxidant defense enzymes like superoxide dismutase (SOD), catalase (CAT), and glutathione peroxidase (GPx) and nonenzymatic antioxidant molecules like glutathione, scorbic acid, and uric acid to protect their cells from the attack of ROS such as superoxide radicals, hydrogen peroxide $\left(\mathrm{H}_{2} \mathrm{O}_{2}\right)$, and hydroxyl radical $\left({ }^{\circ} \mathrm{OH}\right)$ [1]. In this context, it is important to note that thyroid hormones $(\mathrm{TH})$ are critically involved in regulating oxygen consumption and cellular ROS production in several tissues including brain [2-4]. A critical role for TH in the developing brain, specifically the cerebrum and cerebellum, has been well documented $[5,6]$. On the other hand, TH have a critical role in determining the cellular basal metabolic rate and oxygen consumption as well as active oxygen metabolism [7, 8]. It has been observed that a change in thyroid gland function affects production of ROS in rats [2,4]. It has also been reported that hypothyroidism alters the antioxidant defense system in various tissues including several brain regions [9-11]. Peroxisome proliferator-activated receptor gamma 
$(\operatorname{PPAR} \gamma)$ as a member of superfamily of nuclear hormone receptors has been known to be important in adipocyte differentiation, lipid biosynthesis, glucose homeostasis, and immunomodulation $[12,13]$. In addition, PPAR $\gamma$ is also expressed in the central nervous system (CNS) [14, 15]. It is reported that PPAR $\gamma$ agonists thiazolidinediones (TZDs) can provide a protective effect against CNS disorders where an inflammatory response is strongly implicated [14, 15].

It has been well documented that rosiglitazone binds with the highest affinity to PPAR $\gamma[16,17]$. Our knowledge about the effects of PPAR $\gamma$ agonists was initially limited to controlling of lipid metabolism and homeostasis. However, recent studies indicated that $\operatorname{PPAR} \gamma$ activation can regulate oxidative stress responses and expression of a variety of antioxidant molecules [18]. For instance, ligand-activated PPAR $\gamma$ elevates expression of antioxidants including manganese SOD (MnSOD) [19, 20], GPx 3 [21], the scavenger receptor CD36 [22, 23], endothelial nitric oxide synthase (eNOS) [24], heme-oxygenase 1 (HO-1) [25, 26], and the mitochondrial uncoupling protein 2 (UCP2) [27, 28]. Conversely, it downregulates cyclooxygenase 2 (COX-2) and inducible nitric oxide synthase (iNOS) $[12,29,30]$.

It has been reported that the activity of mitochondrial MnSOD, which oversees the dismutation of $\mathrm{O}_{2}{ }^{--}$to $\mathrm{O}_{2}$ and $\mathrm{H}_{2} \mathrm{O}$, is increased by rosiglitazone [19]. Moreover, in PPAR $\gamma$ knockout mice MnSOD is downregulated at the transcriptional and translational levels with a consequent increase of $\mathrm{O}_{2}{ }^{--}$levels [20]. In fact, promoter analysis revealed that MnSOD is a direct target of PPAR $\gamma$ [20]. GPx protects the cells from oxidative stress in two ways: breaking of $\mathrm{H}_{2} \mathrm{O}_{2}$ to $\mathrm{H}_{2} \mathrm{O}$ and $\mathrm{O}$ (like the effect of catalase) and acting as scavenger for oxidized lipids. In addition, beneficial effects of PPAR $\gamma$ agonists in lung [31], heart [32], kidney [33] and, more recently, also the brain $[19,29,34-36]$ have been confirmed.

Thus, this study aimed to determine a protective effect of PPAR $\gamma$ agonists on cerebellar tissues oxidative damage in hypothyroid rats.

\section{Material and Methods}

2.1. Animals and Treatments. Forty-nine male Wistar rats (21 days old and weighing 55-65 g) were kept in standard cages at $22 \pm 2^{\circ} \mathrm{C}$ in a room with a $12 \mathrm{~h}$ light/dark cycle (light on at 7:00 am). Standard food (Javaneh Khorasan, CO, Mashhad, Iran) was available ad libitum. follows:

The rats were divided into seven groups and treated as

Group I (control): the animals received tap drinking water.

Group II (PTU): the animals received 0.05\% PTU in their drinking water during 6 weeks.

Group III: besides $0.05 \%$ PTU in drinking water, the animals were daily injected with $20 \mathrm{mg} / \mathrm{kg}$ vitamin (Vit E).

Groups IV and V: besides $0.05 \%$ PTU in drinking water, the animals were daily injected with 10 or $20 \mathrm{mg} / \mathrm{kg}$ pioglitazone, respectively.
Groups VI and VII: besides 0.05\% PTU in drinking water, the animals were daily injected with 2 or $4 \mathrm{mg} / \mathrm{kg}$ rosiglitazone, respectively.

All injections were done intraperitoneally (IP). Finally, the animals were deeply anesthetized (urethane $1.4 \mathrm{~g} / \mathrm{kg}$ ) and the blood samples were taken to determine hypothyroidism status using the radioimmunoassay method (Diasource, T4RIA-CT). The brains were also removed and the cerebellar tissues were separated. Then, they were made into $10 \%$ tissue homogenate in ice-cold $0.9 \%$ saline solution and were centrifuged $\left(1000 \times \mathrm{g}, 4^{\circ} \mathrm{C}, 10 \mathrm{~min}\right)$ to remove particulates. The obtained supernatants were aliquoted and stored at $-80^{\circ} \mathrm{C}$ to be used for biochemical measurements.

2.2. Biochemical Assessment. The cerebellar tissues were analyzed for total thiol, malondialdehyde (MDA) concentrations, superoxide (SOD), catalase (CAT), and NO metabolites.

MDA levels, as an index of lipid peroxidation, were measured in the cerebellar tissues. MDA reacts with thiobarbituric acid (TBA), a thiobarbituric acid reactive substance (TBARS), and produces a red colored complex which has a peak absorbance at $535 \mathrm{~nm} .2 \mathrm{ml}$ thiobarbituric acid (TBA)/ trichloroacetic acid (TCA)/hydrochloric acid $(\mathrm{HCl})$ reagent was added to $1 \mathrm{ml}$ homogenate and the solution was incubated in a boiling water bath for $40 \mathrm{~min}$. After cooling, the whole solutions were centrifuged $(1000 \times \mathrm{g}$ for $10 \mathrm{~min})$. The absorbance of supernatant was read at $535 \mathrm{~nm}$. The MDA concentration was calculated as previously described $[37,38]$.

Total thiol content was measured using DTNB $\left(2,2^{\prime}\right.$ dinitro-5, $5^{\prime}$-dithiodibenzoic acid) reagent which reacts with the $\mathrm{SH}$ groups and produces a yellow colored complex with a peak absorbance at $412 \mathrm{~nm}$. Briefly, $1 \mathrm{ml}$ Tris-EDTA (ethylenediaminetetraacetic acid) buffer $(\mathrm{pH}=8.6)$ was added to $50 \mu \mathrm{l}$ brain homogenate in $1 \mathrm{ml}$ cuvettes and the absorbance was read at $412 \mathrm{~nm}$ against Tris-EDTA buffer. Then $20 \mu \mathrm{l}$ DTNB reagent $(10 \mathrm{mM}$ in methanol) was added to the mixture and, after $15 \mathrm{~min}$ incubation in room temperature, the absorbance was read again. The absorbance of DTNB reagent was also read as a blank. Total thiol concentration was calculated based on an equation previously described $[37,38]$.

SOD activity was measured by the procedure described by Madesh and Balasubramanian [39]. This procedure is a colorimetric assay based on the generation of superoxide by pyrogallol autoxidation and the inhibition of superoxidedependent reduction of the tetrazolium dye to its formazan by SOD. The colorimetric changes were measured at $570 \mathrm{~nm}$. One unit of SOD activity was defined as the amount of enzyme causing 50\% inhibition in the tetrazolium dye (MTT: (3-(4, 5-dimethylthiazol-2-yl) 2,5-diphenyltetrazolium bromide) reduction rate $[38,40]$.

CAT activity was measured according to the Aebi method. The assay is done based on the rate constant, $k$, (dimension: $\mathrm{s}^{-1}, k$ ) of hydrogen peroxide decomposition. By measuring the reduction in absorbance at $240 \mathrm{~nm}$ per minute, the rate constant of the enzyme was determined [40].

The Griess reaction was adapted to assay nitrates as previously described. Briefly, standard curves for nitrates were prepared and $50 \mu \mathrm{l}$ of tissue suspension was added to the 


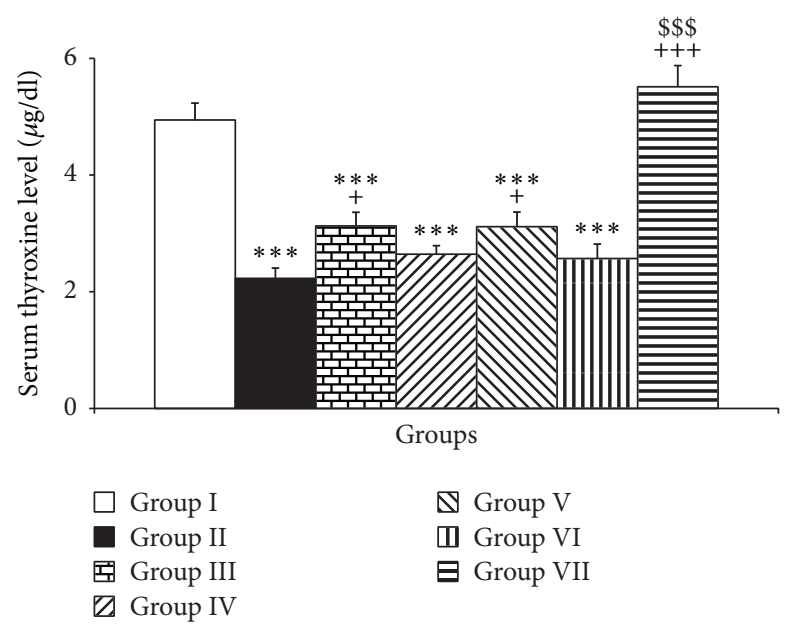

FIGURE 1: The effects of PTU, Vit E, pioglitazone, and rosiglitazone on serum thyroxine concentrations. Data are presented as mean \pm SEM; $n=7 .{ }^{* * *} P<0.001$ versus group $\mathrm{I},{ }^{+} P<0.05$ and ${ }^{+++} P<0.001$ versus group II, and ${ }^{\$ \$ \$} P<0.001$ versus group III. The data from different treatment groups were compared by using one way ANOVA followed by post hoc LSD test. Group I (control), the animals received drinking water; group II, the animals received $0.05 \%$ propylthiouracil (PTU) in drinking water; besides PTU, the animals in groups III, IV, V, VI, and VII were injected with $20 \mathrm{mg} / \mathrm{kg}$ vitamin $\mathrm{E}$ (vit E), 10 or $20 \mathrm{mg} / \mathrm{kg}$ pioglitazone, and 2 or $4 \mathrm{mg} / \mathrm{kg}$ rosiglitazone, respectively.

Griess reagent. The proteins were subsequently precipitated by adding $50 \mu \mathrm{l}$ of $10 \%$ TCA. The contents were then mixed and centrifuged and the supernatants were pulled to a 96well microplate. Absorbance was read at $520 \mathrm{~nm}$ using a microplate reader and final values were calculated from standard calibration plots [41, 42].

2.3. Statistical Analysis. All data were expressed as means \pm SEM. Data were compared by one way ANOVA followed by LSD post hoc comparisons test. Differences were considered statistically significant when $P<0.05$.

\section{Results}

The results showed that the rats of the PTU group had a significantly lower thyroxine concentration in their serum compared to that of control $(P<0.001$, Figure 1$)$ which confirms hypothyroid status of PTU administered rats. The results also showed that Vit $\mathrm{E}$ and higher doses of pioglitazone and rosiglitazone improved the serum thyroxine level compared to PTU $(P<0.05, P<0.01$, and $P<0.001$, respectively, Figure 1).

Furthermore, the PTU exposure influenced MDA and thiol concentrations in the cerebellar tissues. PTU increased MDA in the cerebellar tissues compared to the control group $(P<0.001$, Figure 2). The results also showed that injection of Vit $\mathrm{E}$ and $20 \mathrm{mg} / \mathrm{kg}$ of pioglitazone prevented from increasing the MDA level by PTU $(P<0.01$ increasing the MDA level by PTU $(P<0.01$ and $P<0.001$, respectively, Figure 2); however, $10 \mathrm{mg} / \mathrm{kg}$ of pioglitazone was not effective

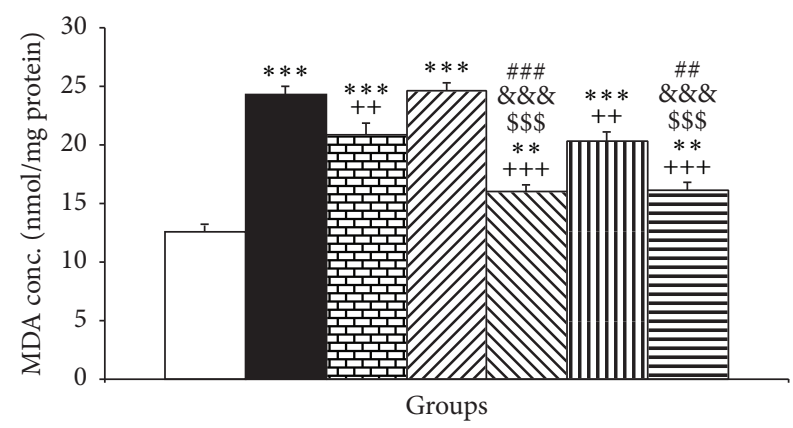

$\begin{array}{ll}\square \text { Group I } & \text { Group V } \\ \text { Group II } & \text { II Group VI } \\ \text { 呂 Group III } & \text { 目 Group VII } \\ \square \text { Group IV } & \end{array}$

FIgURE 2: The effects of PTU, Vit E, pioglitazone, and rosiglitazone on cerebellar MDA concentrations. Data are presented as mean \pm SEM; $n=7$. $^{* *} P<0.01$ and ${ }^{* * *} P<0.001$ versus group $\mathrm{I} ;{ }^{++} P<0.01$ and ${ }^{+++} P<0.001$ versus group II; ${ }^{\$ \$} P<0.001$ versus group III; ${ }^{\& \& \&} P<0.001$ compared to group IV; ${ }^{\# \#} P<0.001$ and ${ }^{\# \#} P<0.01$ compared to group VI. The data from different treatment groups were compared by using one way ANOVA followed by post hoc LSD test. Group I (control), the animals received drinking water; group II, the animals received $0.05 \%$ propylthiouracil (PTU) in drinking water; besides PTU, the animals in groups III, IV, V, VI, and VII were injected with $20 \mathrm{mg} / \mathrm{kg}$ vitamin E (vit E), 10 or $20 \mathrm{mg} / \mathrm{kg}$ pioglitazone, and 2 or $4 \mathrm{mg} / \mathrm{kg}$ rosiglitazone, respectively.

in changing MDA concentrations in the cerebellar tissues of PTU treated rats (Figure 2). Additionally, both doses including 2 and $4 \mathrm{mg} / \mathrm{kg}$ rosiglitazone attenuated the MDA in the cerebellar tissues compared to PTU group $(P<0.01$ and $P<0.001$, respectively, Figure 2 ). The result also showed that the effects of pioglitazone and rosiglitazone were dose dependent $(P<0.01-P<0.001)$. Additionally, both higher doses of pioglitazone and rosiglitazone were more effective than Vit E in attenuating cerebellar MDA compared to PTU $(P<0.001$, Figure 2$)$.

Compared to the control group, PTU also reduced the thiol contents of the cerebellum $(P<0.001$, Figure 3). Treatment of the animals by Vit $\mathrm{E}$ resulted in an increased level of thiol contents in cerebellar tissues compared to PTU group $(P<0.001$, Figure 3$)$. In addition, both doses including 10 and $20 \mathrm{mg} / \mathrm{kg}$ of pioglitazone improved thiol contents of the cerebellar tissues (both $P<0.001$, Figure 3). Furthermore, rosiglitazone in both doses improved the thiol contents compared to the PTU group (both $P<0.001$, Figure 3). Interestingly, the higher doses of both pioglitazone and rosiglitazone were significantly more effective than Vit $\mathrm{E}$ in increasing the thiol contents of the cerebellar tissues (both $P<0.001$, Figure 3). The results also showed that $20 \mathrm{mg} / \mathrm{kg}$ of pioglitazone had significantly higher effect compared to lower dose of pioglitazone to increase thiol concentration in the cerebellum $(P<0.01$, Figure 3$)$. In addition, $4 \mathrm{mg} / \mathrm{kg}$ of rosiglitazone had significantly higher effect compared to lower dose of rosiglitazone $(2 \mathrm{mg} / \mathrm{kg})$ to increase thiol contents in the cerebellum $(P<0.001$, Figure 3$)$. 


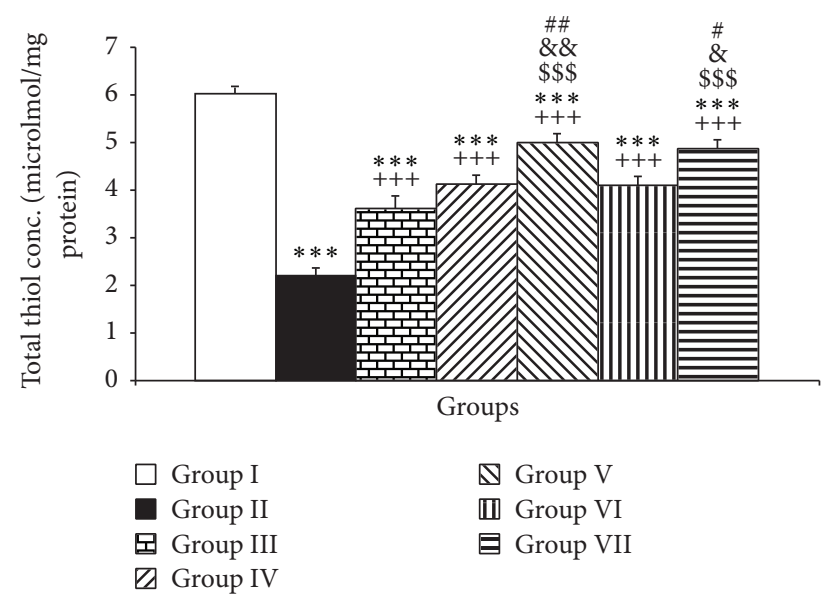

FIgUre 3: The effects of PTU, Vit E, pioglitazone, and rosiglitazone on cerebellar thiol contents. Data are presented as mean \pm SEM; $n=7 .{ }^{* * *} P<0.001$ versus group $\mathrm{I} ;{ }^{+++} P<0.001$ versus group II; ${ }^{\$ \$} P<0.001$ versus group III; ${ }^{\&} P<0.05$ and ${ }^{\& \&} P<0.01$ compared to IV; ${ }^{\#} P<0.05$ and ${ }^{\# \#} P<0.01$ compared to VI. The data from different treatment groups were compared by using one way ANOVA followed by post hoc LSD test. Group I (control), the animals received drinking water; group II, the animals received $0.05 \%$ propylthiouracil (PTU) in drinking water; besides PTU, the animals in groups III, IV, V, VI, and VII were injected with $20 \mathrm{mg} / \mathrm{kg}$ vitamin E (vit E), 10 or $20 \mathrm{mg} / \mathrm{kg}$ pioglitazone, and 2 or $4 \mathrm{mg} / \mathrm{kg}$ rosiglitazone, respectively.

The results also showed that PTU administration diminished the SOD activity in the cerebellum compared to control group $(P<0.001$, Figure 4$)$. Treatment with Vit $\mathrm{E}$ significantly increased the cerebellar SOD compared to the PTU group $(P<0.001$, Figure 4$)$. Additionally, treatment with both doses including 10 and $20 \mathrm{mg} / \mathrm{kg}$ of pioglitazone increased SOD activity compared to PTU $(P<0.001$, Figure 4). Similar to pioglitazone, treatment with both doses of rosiglitazone also improved SOD activity in the cerebellar tissues compared to the PTU group $(P<0.001$, Figure 4$)$. In addition, the cerebellar tissues SOD in the hypothyroid rats treated by both doses of pioglitazone and higher dose of rosiglitazone was higher than that of Vit $\mathrm{E}(P<0.001)$. Compared to Vit E, $2 \mathrm{mg} / \mathrm{kg}$ rosiglitazone had a lower effect in changing SOD activity in the cerebellar tissues of hypothyroid rats $(P<0.01)$. The results also showed that $20 \mathrm{mg} / \mathrm{kg}$ of pioglitazone had a significantly higher effect compared to lower dose of pioglitazone to increase SOD concentration in the cerebellum $(P<0.01$, Figure 4$)$. In addition, $4 \mathrm{mg} / \mathrm{kg}$ of rosiglitazone had a significantly higher effect compared to lower dose of rosiglitazone $(2 \mathrm{mg} / \mathrm{kg})$ to increase SOD in the cerebellum $(P<0.001$, Figure 4$)$.

Additionally, PTU exposure was associated with a significant reduction in CAT activity in the cerebellar tissues compared to control group $(P<0.001$, Figure 5$)$.

Administration of Vit $\mathrm{E}$ and both doses including 10 and $20 \mathrm{mg} / \mathrm{kg}$ of pioglitazone inhibited the lowering effects of PTU on CAT $(P<0.05-P<0.001$, Figure 5$)$. Compared to PTU group, both doses including 2 and $4 \mathrm{mg} / \mathrm{kg}$ were able to significantly increase the CAT activity in the cerebellar tissues

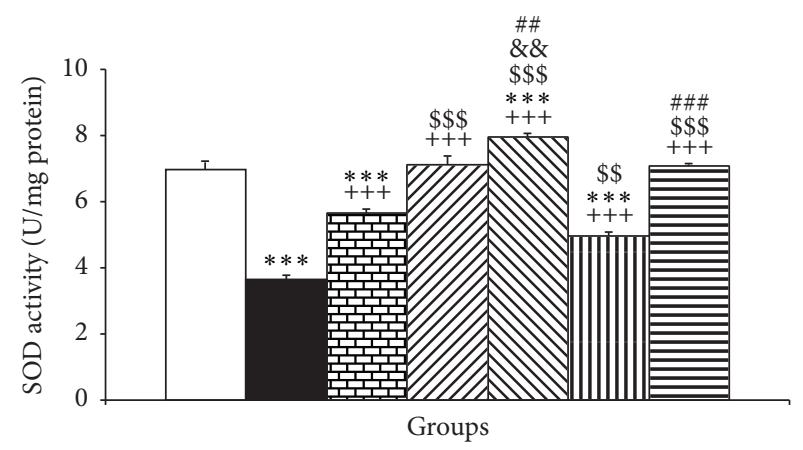

\begin{tabular}{|c|c|}
\hline$\square$ Group I & $\mathbb{\Delta}$ Group V \\
\hline Group II & 向 Group VI \\
\hline 回 Group III & 目 Group VII \\
\hline$\square$ Group IV & \\
\hline
\end{tabular}

FIGURE 4: The effects of PTU, Vit E, pioglitazone, and rosiglitazone on cerebellar SOD. Data are presented as mean \pm SEM; $n=7$. ${ }^{* * *} P<0.001$ versus group $\mathrm{I} ;{ }^{+++} P<0.001$ versus group II; ${ }^{\$ \$} P<$ 0.01 and ${ }^{\$ \$} P<0.001$ versus group III and ${ }^{\& \&} P<0.01$ compared to group IV; ${ }^{\#} P<0.01$ and ${ }^{\# \# \#} P<0.001$ compared to VI. The data from different treatment groups were compared by using one way ANOVA followed by post hoc LSD test. Group I (control), the animals received drinking water; group II, the animals received $0.05 \%$ propylthiouracil (PTU) in drinking water; besides PTU, the animals in groups III, IV, V, VI, and VII were injected with $20 \mathrm{mg} / \mathrm{kg}$ vitamin E (vit E), 10 or $20 \mathrm{mg} / \mathrm{kg}$ pioglitazone, and 2 or $4 \mathrm{mg} / \mathrm{kg}$ rosiglitazone, respectively.

$(P<0.001$, Figure 5$)$. Interestingly both doses of pioglitazone including 10 and $20 \mathrm{mg} / \mathrm{kg}$ and both doses of rosiglitazone including 2 and $4 \mathrm{mg} / \mathrm{kg}$ were more effective than that Vit $\mathrm{E}$ in improving CAT in the cerebellar tissues $(P<0.001$, Figure 5). There was no significant difference between the low and high doses of pioglitazone and also between the two doses of pioglitazone (Figure 5).

The results showed that PTU administration increased the NO metabolites in the cerebellum $(P<0.001$, Figure 6$)$. Compared to PTU group, Vit E was able to attenuate NO metabolites $(P<0.001$, Figure 6$)$. Similar to Vit E, both doses of pioglitazone reduced NO metabolite concentrations $(P<$ 0.001 , Figure 6). Interestingly, both doses of rosiglitazone were able to reduce NO metabolites in the cerebellum of hypothyroid rats $(P<0.001$, Figure 6$)$.

\section{Discussion}

The present study revealed that PPAR $\gamma$ agonists had a protective effect on cerebellar tissues oxidative damage in juvenile hypothyroid rats. Administration of PTU has been frequently used to provide an animal model of hypothyroidism $[4,9]$. It has also been demonstrated that hypothyroidism for 6 weeks brings about a decrease in tissue $\mathrm{T}_{4}$ concentrations in the tissue homogenates of several brain regions including cerebellum [43]. At the subcellular level, nuclear concentration of $\mathrm{T}_{3}$ has been reported to be diminished in the brain during hypothyroidism [43]. In the present investigation, 6-week administration of PTU significantly reduced serum 


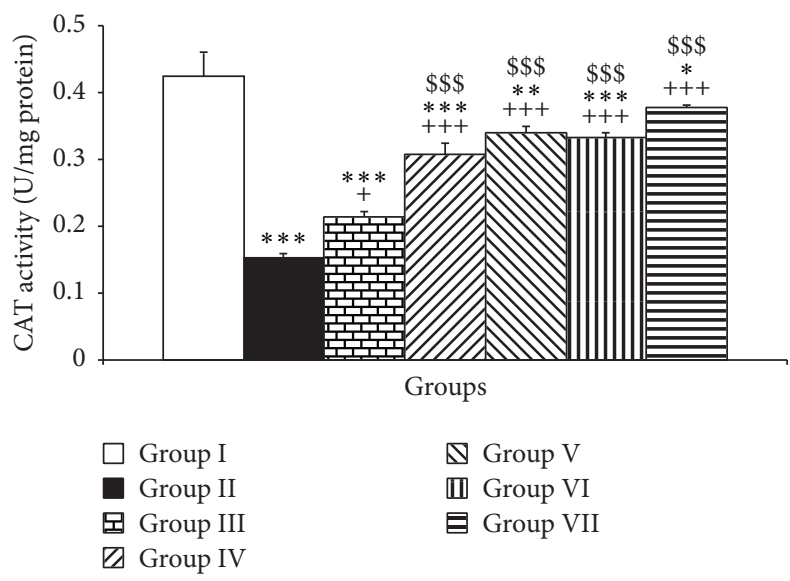

FIgURE 5: The effects of PTU, Vit E, pioglitazone, and rosiglitazone on cerebellar CAT. Data are presented as mean \pm SEM; $n=7$. ${ }^{*} P<0.05,{ }^{* *} P<0.01$, and ${ }^{* * *} P<0.001$ versus group $\mathrm{I} ;{ }^{+} P<0.05$ and ${ }^{+++} P<0.001$ versus group II; ${ }^{\$ \$} P<0.001$ versus group III. The data from different treatment groups were compared by using one way ANOVA followed by post hoc LSD test. Group I (control), the animals received drinking water; group II, the animals received $0.05 \%$ propylthiouracil (PTU) in drinking water; besides PTU, the animals in groups III, IV, V, VI, and VII were injected with $20 \mathrm{mg} / \mathrm{kg}$ vitamin E (vit E), 10 or $20 \mathrm{mg} / \mathrm{kg}$ pioglitazone, and 2 or $4 \mathrm{mg} / \mathrm{kg}$ rosiglitazone, respectively.

$\mathrm{T}_{4}$ level which confirms induction of hypothyroidism in juvenile rats (Figure 1). Interestingly, we observed that highdose rosiglitazone was able to increase $\mathrm{T}_{4}$. The responsible mechanism was not evaluated in the present study. It has been previously reported that rosiglitazone enhances iodine (I) uptake in the thyroid gland $[44,45]$ which may have a role in the results of present study.

The mechanism(s) responsible for the brain dysfunctions due to hypothyroidism seems at least in part to be due to brain tissues oxidative damage $[9,11]$. In the current study, hypothyroidism decreased the antioxidant enzymes activity including SOD (Figure 4) and CAT (Figure 5) which was accompanied by an increased level of MDA (Figure 2) in the cerebellum. The total thiol contents of cerebellar tissues were also decreased (Figure 1). In support of our results, some of the studies reported that hypothyroidism conditions change the activity of the antioxidant status in several tissues including the brain [46-49]. Conversion of hydrogen peroxide to water and molecular oxygen is catalyzed by both CAT and GPx. However, it has been reported that $\mathrm{H}_{2} \mathrm{O}_{2}$ is decomposed by $\mathrm{CAT}$ at high concentration and by GPx at low concentration [1]. On the other hand, some of the studies showed that CAT activity was low in different parts of the brain homogenates of PTU treated rats [50, 51]. Deficiency of catalase has been shown to increase tissue sensitivity to oxidant injury mediated by $\mathrm{H}_{2} \mathrm{O}_{2}$ itself or through Fenton reaction [52]. Interestingly, in the current investigation, a decreased level of CAT activity was observed which may be in response to an increased level of lipid peroxidation in the cerebellum of hypothyroid rats. The enzyme SOD is considered to be the first line of cellular antioxidant defense. A decreased
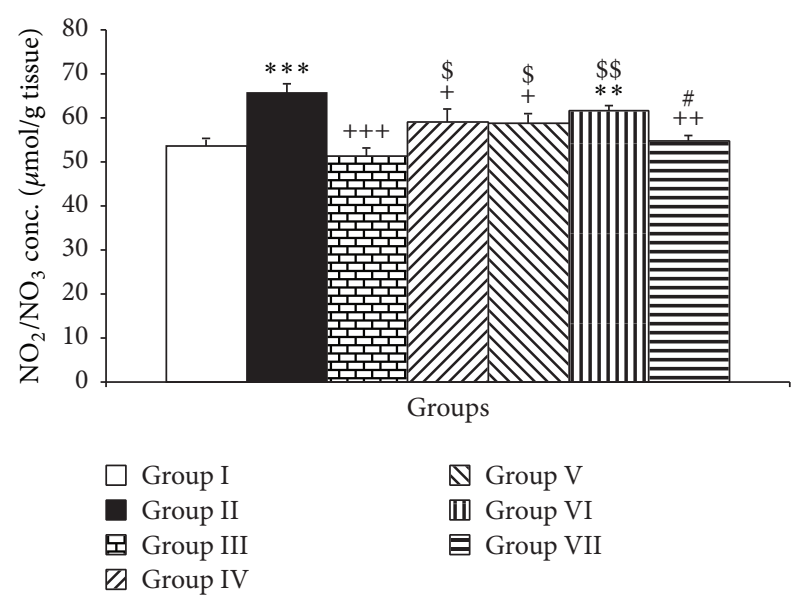

FIgURE 6: The effects of PTU, Vit E, pioglitazone, and rosiglitazone on cerebellar NO metabolites. Data are presented as mean \pm SEM; $n=7 .{ }^{* *} P<0.01$ and ${ }^{* * *} P<0.001$ versus group I; ${ }^{+} P<0.05,{ }^{++} P<0.01$, and ${ }^{+++} P<0.001$ versus group II; ${ }^{\$} P<0.05$ and ${ }^{\$} P<0.01$ versus group III; ${ }^{\#} P<0.05$ compared to group VI. The data from different treatment groups were compared by using one way ANOVA followed by post hoc LSD test. Group I (control), the animals received drinking water; group II, the animals received $0.05 \%$ propylthiouracil (PTU) in drinking water; besides PTU, the animals in groups III, IV, V, VI, and VII were injected with $20 \mathrm{mg} / \mathrm{kg}$ vitamin E (vit E), 10 or $20 \mathrm{mg} / \mathrm{kg}$ pioglitazone, and 2 or $4 \mathrm{mg} / \mathrm{kg}$ rosiglitazone, respectively.

level in SOD activity in the hypothyroid rats might trigger increasing of $\mathrm{O}_{2}{ }^{-}$which finally leads to increasing of lipid peroxidation. $\mathrm{SOD}$ is also able to scavenge $\mathrm{O}^{-}$by dismutating it to $\mathrm{H}_{2} \mathrm{O}_{2}$ which can freely move across cell membranes and cause oxidative modification [1]. Regarding this evidence it seems that a decreased level of SOD and CAT has a role in increasing of lipid peroxidation which was observed in the present study after PTU administration. The results of our study are consistent with Pan et al. [53] who found that MDA level was elevated while SOD level was decreased in the hippocampus of hypothyroid rats. Baskol et al. [54] also investigated a relationship between the serum levels of MDA and SOD activity as a marker of oxidant-antioxidant system and thyroid hormone status in hypothyroidism. They showed that SOD activity was significantly higher while MDA level was lower after treatment when compared to the pretreatment of hypothyroid patients. These findings and the results of present study may suggest an imbalance between oxidant and antioxidant system as a leading factor to the brain tissues such as cerebellum oxidative damage in hypothyroidism.

Other studies $[4,55,56]$ have also shown that hypothyroidism is associated with a decline in thiol level such as GSH in the brain. Dasgupta et al. $[55,56]$ reported that a reduction in specific activity of cerebral glutamate cysteine ligase and c-glutamyl transpeptidase, the key enzyme in regulation of GSH, occurs as a response to postnatal hypothyroidism. Thyroid hormone is known to play a helpful role in maintaining GSH homeostasis in astrocytes thereby protecting the brain from oxidative stress induced pathophysiological conditions [57]. 
Regarding these facts beneficial effects of the antioxidants on the brain tissues' oxidative damage due to hypothyroidism are conceivable. Beneficial effects of Vit $\mathrm{E}$ as a well-known antioxidant agent on the brain tissues' oxidative damage have been well documented $[34,53]$. The antioxidant properties of $\operatorname{PPAR} \gamma$ agonists such as pioglitazone and rosiglitazone have been well documented [58]. A protection profile of PPAR $\gamma$ agonists against tissues' oxidative damage in an animal model of ischemia/reperfusion $[34,59]$ as well as in other conditions such as burns [60] has been reported. Considering these properties, it was assumed that rosiglitazone and pioglitazone might be effective in protecting the cerebellar tissues from oxidative damage in PTU induced hypothyroidism conditions. The results showed that, in a similar manner to Vit E, both drugs prevented from increasing of MDA in the cerebellar tissues of hypothyroid rats. To the best of our knowledge, this is the first report which shows that PPAR $\gamma$ agonists pioglitazone and rosiglitazone are able to protect the cerebellum of juvenile hypothyroid rats from oxidative stress.

Our results showed that administration of pioglitazone or rosiglitazone in hypothyroid rat decreased cerebellar lipid peroxidation. Similarly, both drugs offered a significant improving effect on SOD and CAT activity. These data suggest that the protective effects of rosiglitazone and pioglitazone against hypothyroidism injury are partially due to their ability to reduce oxidative stress. In support of the results of present study, pioglitazone pretreatment has been shown to inhibit reactive oxygen species production in cardiac fibroblasts exposed to hypoxia/reoxygenation [61] and to reduce renal oxidative stress in obese rats [62].

Various mechanisms may involve elucidating the effects of PPAR $\gamma$ agonists on oxidative stress parameters in the cerebellum of the rats. First, it has been well documented that activation of PPAR $\gamma$ has beneficial effects on expression of antioxidant enzymes including SOD, $\mathrm{GPx}_{3}$, and CAT [58, 63]. An increased level of the antioxidant enzymes activities including CAT and SOD by PPAR $\gamma$ agonists has also been reported [64]. Therefore, an increased level of CAT and SOD activities may be responsible for the beneficial effects of rosiglitazone or pioglitazone which were observed in the present study. Second, mitochondria are the major source of reactive oxygen species, which are mainly generated at complexes I and III of the respiratory chain [65]. There is now evidence that PPAR $\gamma$ agonists exert direct and rapid effects on mitochondrial respiration, inhibiting complex I [66] and complex III [67] activities. As PPAR $\gamma$ agonists partially disrupt the mitochondrial respiratory chain, both electron transport and superoxide anion generation are affected. Moreover, a novel mitochondrial target protein for PPAR $\gamma$ agonists ("mitoNEET") has recently been identified [68]. MitoNEET was found to be associated with components of complex III, suggesting how PPAR $\gamma$ agonists binding to mitoNEET could selectively block different mitochondrial targets. Third, in addition, it has been demonstrated that PPAR $\gamma$ agonists are able to inhibit mitochondrial pyruvate carrier (MPC) [69]. Therefore, a reduction in intramitochondrial pyruvate level would be able to stimulate mitochondrial malic enzyme activity; the alter produces pyruvate from malate and then increases $\mathrm{NAD}(\mathrm{P}) \mathrm{H}$ levels. An increased level in $\mathrm{NAD}(\mathrm{P}) \mathrm{H}$ is able to elevate GSH production. Therefore, MPC inhibition may decrease free radical levels by enhancing GSH levels. Taking into account these findings, PPAR $\gamma$ agonists' ability to influence mitochondrial function might be attributed to their inhibitory effects on reactive oxygen species generation evoked by hypothyroidism.

Another important molecule involved in the oxidative pathway leading to cell damage is nitric oxide (NO). Under pathological conditions, NO possibly promotes oxidative damage, through the formation of a highly reactive metabolite peroxynitrite [70, 71]. A relationship between thyroid hormones and the NO system has been confirmed [72-74]. Many studies showed that thyroid hormones act as regulating of NO synthase gene expression in the brain $[41,75,76]$. It is also suggested that hypothyroidism increases nNOS activity and NO in amygdala and hippocampus $[41,75]$. On the one hand, under pathological conditions, NO reacts with superoxide and produces peroxynitrite, a powerful oxidant, which is able to damage many biological molecules [70, 71, 77]. Moreover, NO induces a mitochondrial dysfunction due to damaging of the complexes of respiratory chain, (complexes I-III, II-III, and cytochrome c oxidase) which finally lead to a more formed superoxide radicals $[2,78]$. In the present study, both PPAR $\gamma$ agonists reduced NO metabolites which might be considered as another mechanism(s) responsible for their beneficial effects.

In conclusion, the results of present study showed for the first time that the PPAR $\gamma$ agonists rosiglitazone and pioglitazone exert protective effects against cerebellar injury in hypothyroidism by protecting against tissues' oxidative damage.

\section{Ethical Approval}

The Ethics Committee for Animal Experiments at Mashhad University of Medical Sciences approved the study and all experiments were conducted in accordance with the National Institute of Health Guide for the Care and Use of Laboratory Animals.

\section{Competing Interests}

The authors declare that there is no conflict of interests.

\section{Acknowledgments}

The authors would like to thank the Vice President of Research in Mashhad University of Medical Sciences for the financial support. The presented results were from a Ph.D. student's thesis.

\section{References}

[1] B. Halliwell and J. M. Gutteridge, Free Radicals in Biology and Medicine, Oxford University Press, Oxford, UK, 2001.

[2] P. Venditti and S. Di Meo, "Thyroid hormone-induced oxidative stress," Cellular and Molecular Life Sciences, vol. 63, no. 4, pp. 414-434, 2006. 
[3] R. Mogulkoc, A. K. Baltaci, L. Aydin, E. Oztekin, and A. Sivrikaya, "The effect of thyroxine administration on lipid peroxidation in different tissues of rats with hypothyroidism," Acta Physiologica Hungarica, vol. 92, no. 1, pp. 39-46, 2005.

[4] S. O. Rahaman, S. Ghosh, K. P. Mohanakumar, S. Das, and P. Kumar Sarkar, "Hypothyroidism in the developing rat brain is associated with marked oxidative stress and aberrant intraneuronal accumulation of neurofilaments," Neuroscience Research, vol. 40, no. 3, pp. 273-279, 2001.

[5] C. C. Thompson and G. B. Potter, "Thyroid hormone action in neural development," Cerebral Cortex, vol. 10, no. 10, pp. 939945, 2000.

[6] J. H. Oppenheimer and H. L. Schwartz, "Molecular basis of thyroid hormone-dependent brain development," Endocrine Reviews, vol. 18, no. 4, pp. 462-475, 1997.

[7] B. Martinez, P. Del Hoyo, M. A. Martin, J. Arenas, A. PerezCastillo, and A. Santos, "Thyroid hormone regulates oxidative phosphorylation in the cerebral cortex and striatum of neonatal rats," Journal of Neurochemistry, vol. 78, no. 5, pp. 1054-1063, 2001.

[8] S. S. Katyare, C. S. Bangur, and J. L. Howland, "Is respiratory activity in the brain mitochondria responsive to thyroid hormone action?: a critical re-evaluation," Biochemical Journal, vol. 302, no. 3, pp. 857-860, 1994.

[9] D. Cattani, P. B. Goulart, V. L. D. L. O. Cavalli et al., "Congenital hypothyroidism alters the oxidative status, enzyme activities and morphological parameters in the hippocampus of developing rats," Molecular and Cellular Endocrinology, vol. 375, no. 1-2, pp. 14-26, 2013.

[10] A. Abedelhaffez and A. Hassan, "Brain derived neurotrophic factor and oxidative stress index in pups with developmental hypothyroidism: neuroprotective effects of selenium," Acta Physiologica Hungarica, vol. 100, no. 2, pp. 197-210, 2013.

[11] S. Bhanja and G. B. N. Chainy, "PTU-induced hypothyroidism modulates antioxidant defence status in the developing cerebellum," International Journal of Developmental Neuroscience, vol. 28, no. 3, pp. 251-262, 2010.

[12] M. Ricote, A. C. Li, T. M. Willson, C. J. Kelly, and C. K. Glass, "The peroxisome proliferator-activated receptor- $\gamma$ is a negative regulator of macrophage activation," Nature, vol. 391, no. 6662, pp. 79-82, 1998.

[13] C. Jiang, A. T. Ting, and B. Seed, "PPAR- $\gamma$ agonists inhibit production of monocyte inflammatory cytokines," Nature, vol. 391, no. 6662, pp. 82-86, 1998.

[14] G. E. Landreth and M. T. Heneka, "Anti-inflammatory actions of peroxisome proliferator-activated receptor gamma agonists in Alzheimer's disease," Neurobiology of Aging, vol. 22, no. 6, pp. 937-944, 2001.

[15] T. Dehmer, M. T. Heneka, M. Sastre, J. Dichgans, and J. B. Schulz, "Protection by pioglitazone in the MPTP model of Parkinson's disease correlates with $\mathrm{I} \kappa \mathrm{B} \alpha$ induction and block of $\mathrm{NF} \kappa \mathrm{B}$ and iNOS activation," Journal of Neurochemistry, vol. 88, no. 2, pp. 494-501, 2004.

[16] J. M. Lehmann, L. B. Moore, T. A. Smith-Oliver, W. O. Wilkison, T. M. Willson, and S. A. Kliewer, "An antidiabetic thiazolidinedione is a high affinity ligand for peroxisome proliferatoractivated receptor $\gamma(\operatorname{PPAR} \gamma)$," The Journal of Biological Chemistry, vol. 270, no. 22, pp. 12953-12956, 1995.

[17] T. M. Willson, J. E. Cobb, D. J. Cowan et al., “The structureactivity relationship between peroxisome proliferator-activated receptor $\gamma$ agonism and the antihyperglycemic activity of thiazolidinediones," Journal of Medicinal Chemistry, vol. 39, no. 3, pp. 665-668, 1996.

[18] T. Kielian and P. D. Drew, "Effects of peroxisome proliferatoractivated receptor- $\gamma$ agonists on central nervous system inflammation," Journal of Neuroscience Research, vol. 71, no. 3, pp. 315325, 2003.

[19] X. Yu, X.-G. Shao, H. Sun et al., "Activation of cerebral peroxisome proliferator-activated receptors gamma exerts neuroprotection by inhibiting oxidative stress following pilocarpineinduced status epilepticus," Brain Research, vol. 1200, pp. 146158, 2008.

[20] G. Ding, M. Fu, Q. Qin et al., "Cardiac peroxisome proliferatoractivated receptor $\delta$ is essential in protecting cardiomyocytes from oxidative damage," Cardiovascular Research, vol. 76, no. 2, pp. 269-279, 2007.

[21] S. S. Chung, M. Kim, B.-S. Youn et al., "Glutathione peroxidase 3 mediates the antioxidant effect of peroxisome proliferatoractivated receptor $\gamma$ in human skeletal muscle cells," Molecular and Cellular Biology, vol. 29, no. 1, pp. 20-30, 2009.

[22] T. Ishii, K. Itoh, E. Ruiz et al., "Role of Nrf2 in the regulation of CD36 and stress protein expression in murine macrophages: activation by oxidatively modified LDL and 4-hydroxynonenal," Circulation Research, vol. 94, no. 5, pp. 609-616, 2004.

[23] L. Nagy, P. Tontonoz, J. G. A. Alvarez, H. Chen, and R. M. Evans, "Oxidized LDL regulates macrophage gene expression through ligand activation of PPAR $\gamma$," Cell, vol. 93, no. 2, pp. 229-240, 1998.

[24] J. M. Kleinhenz, D. J. Kleinhenz, S. You et al., "Disruption of endothelial peroxisome proliferator-activated receptor- $\gamma$ reduces vascular nitric oxide production," American Journal of Physiology-Heart and Circulatory Physiology, vol. 297, no. 5, pp. H1647-H1654, 2009.

[25] X. Wang, Z. Wang, J. Z. Liu et al., "Double antioxidant activities of rosiglitazone against high glucose-induced oxidative stress in hepatocyte," Toxicology in Vitro, vol. 25, no. 4, pp. 839-847, 2011.

[26] A. A. Herzlich, X. Ding, D. Shen, R. J. Ross, J. Tuo, and C. Chan, "Peroxisome proliferator-activated receptor expression in murine models and humans with age-related macular degeneration," The Open Biology Journal, vol. 2, no. 1, pp. 141-148, 2009.

[27] A. Pautz, J. Art, S. Hahn, S. Nowag, C. Voss, and H. Kleinert, "Regulation of the expression of inducible nitric oxide synthase," Nitric Oxide - Biology and Chemistry, vol. 23, no. 2, pp. 75-93, 2010.

[28] A. Galli, T. Mello, and S. Polvani, "Peroxisome proliferatoractivated receptor and retinoic $\mathrm{X}$ receptor in alcoholic liver disease," PPAR Research, vol. 2009, Article ID 748174, 11 pages, 2009.

[29] T. Shimazu, I. Inoue, N. Araki et al., "A peroxisome proliferatoractivated receptor- $\gamma$ agonist reduces infarct size in transient but not in permanent ischemia," Stroke, vol. 36, no. 2, pp. 353-359, 2005.

[30] N. Khandoudi, P. Delerive, I. Berrebi-Bertrand, R. E. Buckingham, B. Staels, and A. Bril, "Rosiglitazone, a peroxisome proliferator-activated receptor- $\gamma$, inhibits the Jun $\mathrm{NH}_{2}$-terminal kinase/activating protein 1 pathway and protects the heart from ischemia/reperfusion injury," Diabetes, vol. 51, no. 5, pp. 15071514, 2002.

[31] M. Okada, S. F. Yan, and D. J. Pinsky, "Peroxisome proliferatoractivated receptor- $\gamma$ (PPAR- $\gamma$ ) activation suppresses ischemic induction of Egr-1 and its inflammatory gene targets," The FASEB Journal, vol. 16, no. 14, pp. 1861-1868, 2002. 
[32] N. S. Wayman, Y. Hattori, M. C. Mcdonald et al., "Ligands of the peroxisome proliferator-activated receptors (PPAR- $\gamma$ and PPAR- $\alpha$ ) reduce myocardial infarct size," FASEB Journal, vol. 16, no. 9, pp. 1027-1040, 2002.

[33] H.-C. Yang, S. Deleuze, Y. Zuo, S. A. Potthoff, L.-J. Ma, and A. B. Fogo, "The PPAR $\gamma$ agonist pioglitazone ameliorates agingrelated progressive renal injury," Journal of the American Society of Nephrology, vol. 20, no. 11, pp. 2380-2388, 2009.

[34] M. Collino, M. Aragno, R. Mastrocola et al., "Modulation of the oxidative stress and inflammatory response by PPAR$\gamma$ agonists in the hippocampus of rats exposed to cerebral ischemia/reperfusion," European Journal of Pharmacology, vol. 530, no. 1-2, pp. 70-80, 2006.

[35] S. Sundararajan, J. L. Gamboa, N. A. Victor, E. W. Wanderi, W. D. Lust, and G. E. Landreth, "Peroxisome proliferator-activated receptor- $\gamma$ ligands reduce inflammation and infarction size in transient focal ischemia," Neuroscience, vol. 130, no. 3, pp. 685696, 2005.

[36] M. Collino, N. S. A. Patel, and C. Thiemermann, "Review: PPARs as new therapeutic targets for the treatment of cerebral ischemia/reperfusion injury," Therapeutic Advances in Cardiovascular Disease, vol. 2, no. 3, pp. 179-197, 2008.

[37] S. Choopankareh, F. Vafaee, M. N. Shafei et al., "Effects of melatonin and theanine administration on pentylenetetrazoleinduced seizures and brain tissue oxidative damage in ovariectomized rats," Turkish Journal of Medical Sciences, vol. 45, no. 4, pp. 842-849, 2015.

[38] A. Anaeigoudari, M. N. Shafei, M. Soukhtanloo et al., "Lipopolysaccharide-induced memory impairment in rats is preventable using 7-nitroindazole," Arquivos de NeuroPsiquiatria, vol. 73, no. 9, pp. 784-790, 2015.

[39] M. Madesh and K. A. Balasubramanian, "Microtiter plate assay for superoxide dismutase using MTT reduction by superoxide," Indian Journal of Biochemistry \& Biophysics, vol. 35, no. 3, pp. 184-188, 1998.

[40] A. Anaeigoudari, M. Soukhtanloo, M. N. Shafei et al., "Neuronal nitric oxide synthase has a role in the detrimental effects of lipopolysaccharide on spatial memory and synaptic plasticity in rats," Pharmacological Reports, vol. 68, no. 2, pp. 243-249, 2016.

[41] M. Hosseini, S. S. Dastghaib, H. Rafatpanah, M. A.-R. Hadjzadeh, H. Nahrevanian, and I. Farrokhi, "Nitric oxide contributes to learning and memory deficits observed in hypothyroid rats during neonatal and juvenile growth," Clinics, vol. 65, no. 11, pp. 1175-1181, 2010.

[42] M. Hosseini, F. Harandizadeh, S. Niazmand, M. Soukhtanloo, A. Faizpour, and M. Ghasemabady, "The role for nitric oxide on the effects of hydroalcoholic extract of Achillea wilhelmsii on seizure," Avicenna Journal of Phytomedicine, vol. 4, pp. 251-259, 2014.

[43] O. Broedel, M. Eravci, S. Fuxius et al., "Effects of hyper- and hypothyroidism on thyroid hormone concentrations in regions of the rat brain," American Journal of Physiology - Endocrinology and Metabolism, vol. 285, no. 3, pp. E470-E480, 2003.

[44] E. Kebebew, M. Peng, E. Reiff et al., "A phase II trial of rosiglitazone in patients with thyroglobulin-positive and radioiodinenegative differentiated thyroid cancer," Surgery, vol. 140, no. 6, pp. 960-967, 2006.

[45] S. Tepmongkol, S. Keelawat, S. Honsawek, and P. Ruangvejvorachai, "Rosiglitazone effect on radioiodine uptake in thyroid carcinoma patients with high thyroglobulin but negative total body scan: a correlation with the expression of peroxisome proliferator-activated receptor-gamma," Thyroid, vol. 18, no. 7, pp. 697-704, 2008.

[46] S. Jena, G. B. N. Chainy, and J. Dandapat, "Hypothyroidism modulates renal antioxidant gene expression during postnatal development and maturation in rat," General and Comparative Endocrinology, vol. 178, no. 1, pp. 8-18, 2012.

[47] D. K. Sahoo, A. Roy, S. Bhanja, and G. B. N. Chainy, "Hypothyroidism impairs antioxidant defence system and testicular physiology during development and maturation," General and Comparative Endocrinology, vol. 156, no. 1, pp. 63-70, 2008.

[48] S. Chattopadhyay, D. K. Sahoo, U. Subudhi, and G. B. N. Chainy, "Differential expression profiles of antioxidant enzymes and glutathione redox status in hyperthyroid rats: a temporal analysis," Comparative Biochemistry and Physiology Part C: Toxicology \& Pharmacology, vol. 146, no. 3, pp. 383-391, 2007.

[49] K. Das and G. B. N. Chainy, "Thyroid Hormone influences antioxidant defense system in adult rat brain," Neurochemical Research, vol. 29, no. 9, pp. 1755-1766, 2004.

[50] S. Bhanja and S. Jena, "Modulation of antioxidant enzyme expression by PTU-induced hypothyroidism in cerebral cortex of postnatal rat brain," Neurochemical Research, vol. 38, no. 1, pp. 42-49, 2013.

[51] S. Jena and S. Bhanja, "Hypothyroidism alters antioxidant defence system in rat brainstem during postnatal development and adulthood," Neurological Sciences, vol. 35, no. 8, pp. 12691274, 2014.

[52] Y.-S. Ho, Y. Xiong, W. Ma, A. Spector, and D. S. Ho, "Mice lacking catalase develop normally but show differential sensitivity to oxidant tissue injury," The Journal of Biological Chemistry, vol. 279, no. 31, pp. 32804-32812, 2004.

[53] T. Pan, M. Zhong, X. Zhong, Y. Zhang, and D. Zhu, "Levothyroxine replacement therapy with vitamin E supplementation prevents oxidative stress and cognitive deficit in experimental hypothyroidism," Endocrine, vol. 43, no. 2, pp. 434-439, 2013.

[54] G. Baskol, H. Atmaca, F. Tanriverdi, M. Baskol, D. Kocer, and F. Bayram, "Oxidative stress and enzymatic antioxidant status in patients with hypothyroidism before and after treatment," Experimental and Clinical Endocrinology and Diabetes, vol. 115, no. 8, pp. 522-526, 2007.

[55] A. Dasgupta, S. Das, and P. K. Sarkar, "Thyroid hormone promotes glutathione synthesis in astrocytes by up regulation of glutamate cysteine ligase through differential stimulation of its catalytic and modulator subunit mRNAs," Free Radical Biology and Medicine, vol. 42, no. 5, pp. 617-626, 2007.

[56] A. Dasgupta, S. Das, and P. K. Sarkar, "Thyroid hormone stimulates $\gamma$-glutamyl transpeptidase in the developing rat cerebra and in astroglial cultures," Journal of Neuroscience Research, vol. 82 , no. 6, pp. 851-857, 2005.

[57] O. M. Ahmed, A. El-Gareib, A. El-Bakry, S. A. El-Tawab, and R. Ahmed, "Thyroid hormones states and brain development interactions," International Journal of Developmental Neuroscience, vol. 26, pp. 147-209, 2008.

[58] S. Polvani, M. Tarocchi, and A. Galli, "PPAR $\gamma$ and oxidative stress: $\operatorname{con}(\beta)$ catenating NRF2 and FOXO," PPAR Research, vol. 2012, Article ID 641087, 15 pages, 2012.

[59] I. Villegas, A. R. Martín, W. Toma, and C. Alarcón De La Lastra, "Rosiglitazone, an agonist of peroxisome proliferator-activated receptor gamma, protects against gastric ischemia-reperfusion damage in rats: role of oxygen free radicals generation," European Journal of Pharmacology, vol. 505, no. 1-3, pp. 195-203, 2004. 
[60] G. Şener, A. Ö. Şehirli, N. Gedik, and G. A. Dülger, "Rosiglitazone, a PPAR- $\gamma$ ligand, protects against burn-induced oxidative injury of remote organs," Burns, vol. 33, no. 5, pp. 587-593, 2007.

[61] K. Chen, D. Li, X. Zhang, P. L. Hermonat, and J. L. Mehta, "Anoxia-reoxygenation stimulates collagen type-I and MMP1 expression in cardiac fibroblasts: modulation by the PPAR- $\gamma$ ligand pioglitazone," Journal of Cardiovascular Pharmacology, vol. 44, no. 6, pp. 682-687, 2004.

[62] A. D. Dobrian, S. D. Schriver, A. A. Khraibi, and R. L. Prewitt, "Pioglitazone prevents hypertension and reduces oxidative stress in diet-induced obesity," Hypertension, vol. 43, no. 1, pp. 48-56, 2004.

[63] E. Gray, M. Ginty, K. Kemp, N. Scolding, and A. Wilkins, "The PPAR-gamma agonist pioglitazone protects cortical neurons from inflammatory mediators via improvement in peroxisomal function," Journal of Neuroinflammation, vol. 9, article 63, 2012.

[64] M. M. El-Naa, M. F. El-Refaei, W. A. Nasif, S. H. Abduljawad, A. I. El-Brairy, and M. Z. El-Readi, "In-vivo antioxidant and anti-inflammatory activity of rosiglitazone, a peroxisome proliferator-activated receptor-gamma (PPAR- $\gamma$ ) agonists in animal model of bronchial asthma," Journal of Pharmacy and Pharmacology, vol. 67, no. 10, pp. 1421-1430, 2015.

[65] A. P. Kudin, G. Debska-Vielhaber, and W. S. Kunz, "Characterization of superoxide production sites in isolated rat brain and skeletal muscle mitochondria," Biomedicine and Pharmacotherapy, vol. 59, no. 4, pp. 163-168, 2005.

[66] B. Brunmair, K. Staniek, F. Gras et al., "Thiazolidinediones, like metformin, inhibit respiratory complex I: a common mechanism contributing to their antidiabetic actions?" Diabetes, vol. 53, no. 4, pp. 1052-1059, 2004.

[67] C. Dello Russo, V. Gavrilyuk, G. Weinberg et al., "Peroxisome proliferator-activated receptor $\gamma$ thiazolidinedione agonists increase glucose metabolism in astrocytes," Journal of Biological Chemistry, vol. 278, no. 8, pp. 5828-5836, 2003.

[68] J. R. Colca, W. G. McDonald, D. J. Waldon et al., "Identification of a novel mitochondrial protein ('mitoNEET') cross-linked specifically by a thiazolidinedione photoprobe," American Journal of Physiology-Endocrinology and Metabolism, vol. 286, no. 2, pp. E252-E260, 2004.

[69] A. S. Divakaruni, S. E. Wiley, G. W. Rogers et al., "Thiazolidinediones are acute, specific inhibitors of the mitochondrial pyruvate carrier," Proceedings of the National Academy of Sciences of the United States of America, vol. 110, no. 14, pp. 5422-5427, 2013.

[70] P.-E. Chabrier, C. Demerlé-Pallardy, and M. Auguet, "Nitric oxide synthases: targets for therapeutic strategies in neurological diseases," Cellular and Molecular Life Sciences, vol. 55, no. 8, pp. 1029-1035, 1999.

[71] R. R. Jonnala and J. J. Buccafusco, "Inhibition of nerve growth factor signaling by peroxynitrite," Journal of Neuroscience Research, vol. 63, no. 1, pp. 27-34, 2001.

[72] G. A. Böhme, C. Bon, J.-M. Stutzmann, A. Doble, and J.-C. Blanchard, "Possible involvement of nitric oxide in long-term potentiation," European Journal of Pharmacology, vol. 199, no. 3, pp. 379-381, 1991.

[73] K. Shibuki and D. Okada, "Endogenous nitric oxide release required for long-term synaptic depression in the cerebellum," Nature, vol. 349, no. 6307, pp. 326-328, 1991.

[74] Y. Ueta, A. Levy, H. S. Chowdrey, and S. L. Lightman, "Hypothalamic nitric oxide synthase gene expression is regulated by thyroid hormones," Endocrinology, vol. 136, no. 10, pp. 41824187, 1995.
[75] E. Cano-Europa, F. Pérez-Severiano, P. Vergara et al., "Hypothyroidism induces selective oxidative stress in amygdala and hippocampus of rat," Metabolic Brain Disease, vol. 23, no. 3, pp. 275-287, 2008.

[76] R. A. Sinha, A. Pathak, V. Mohan, S. Bandyopadhyay, L. Rastogi, and M. M. Godbole, "Maternal thyroid hormone: a strong repressor of neuronal nitric oxide synthase in rat embryonic neocortex," Endocrinology, vol. 149, no. 9, pp. 4396-4401, 2008.

[77] R. Radi, A. Cassina, R. Hodara, C. Quijano, and L. Castro, "Peroxynitrite reactions and formation in mitochondria," Free Radical Biology and Medicine, vol. 33, no. 11, pp. 1451-1464, 2002.

[78] M. C. Franco, V. G. Antico Arciuch, J. G. Peralta et al., "Hypothyroid phenotype is contributed by mitochondrial complex I inactivation due to translocated neuronal nitric-oxide synthase," Journal of Biological Chemistry, vol. 281, no. 8, pp. 4779-4786, 2006. 


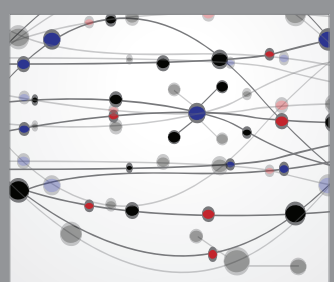

The Scientific World Journal
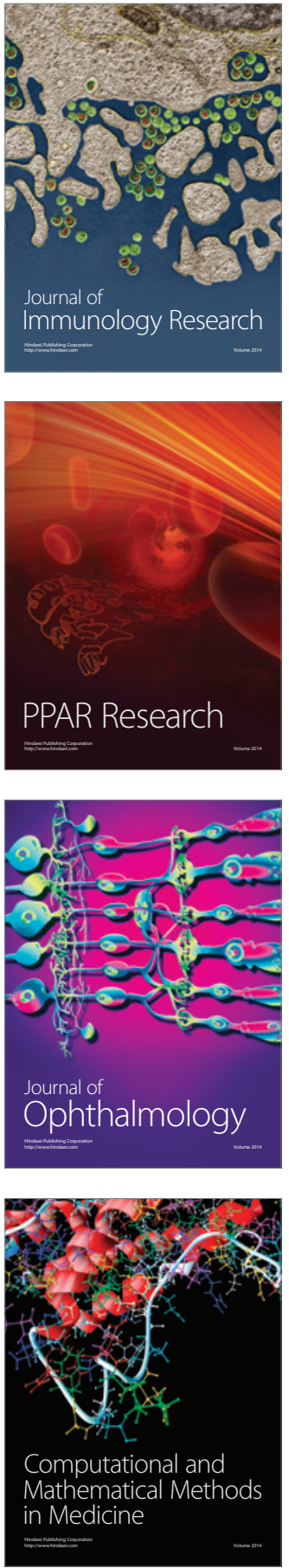

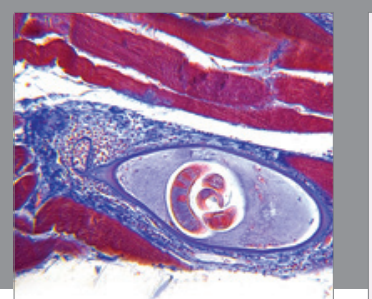

Gastroenterology Research and Practice

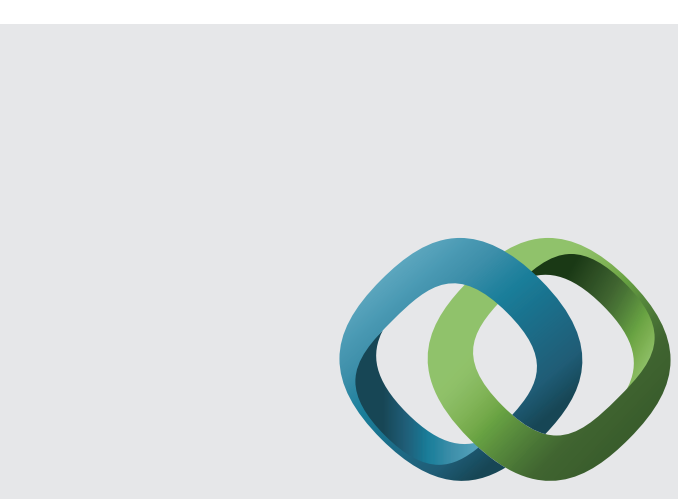

\section{Hindawi}

Submit your manuscripts at

http://www.hindawi.com
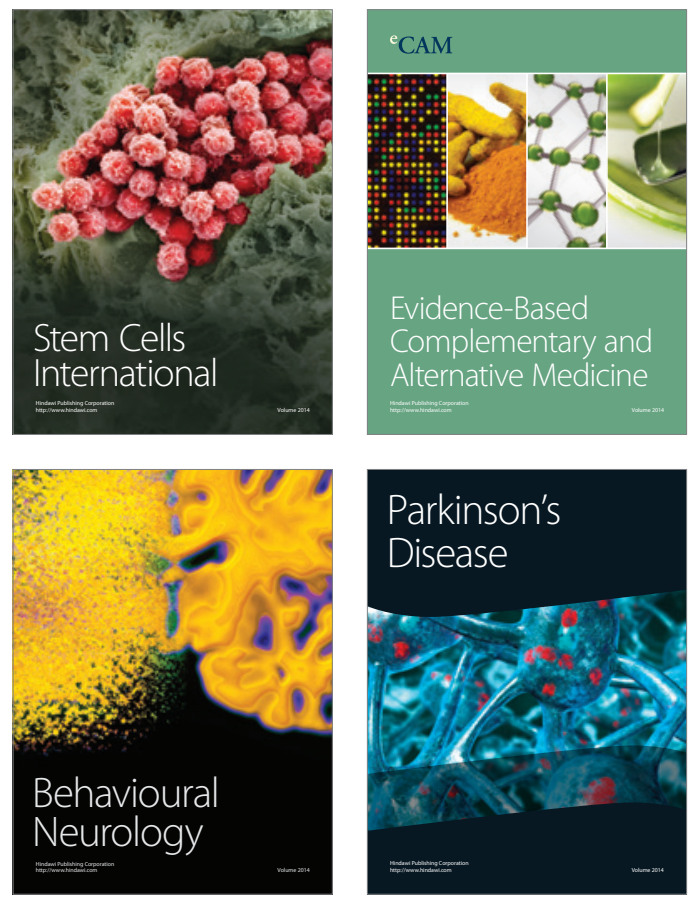
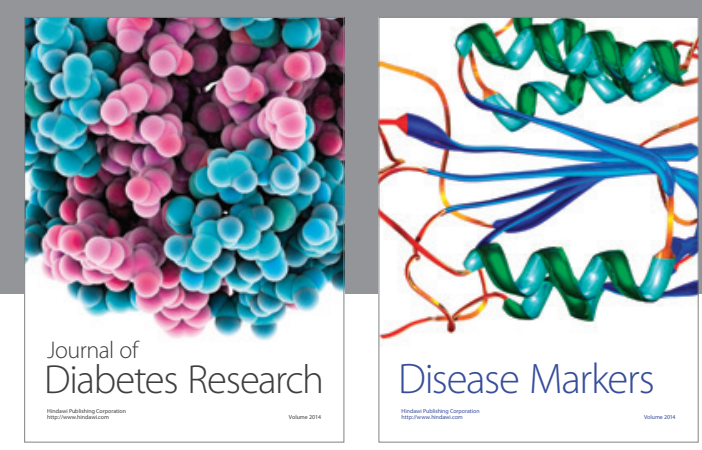

Disease Markers
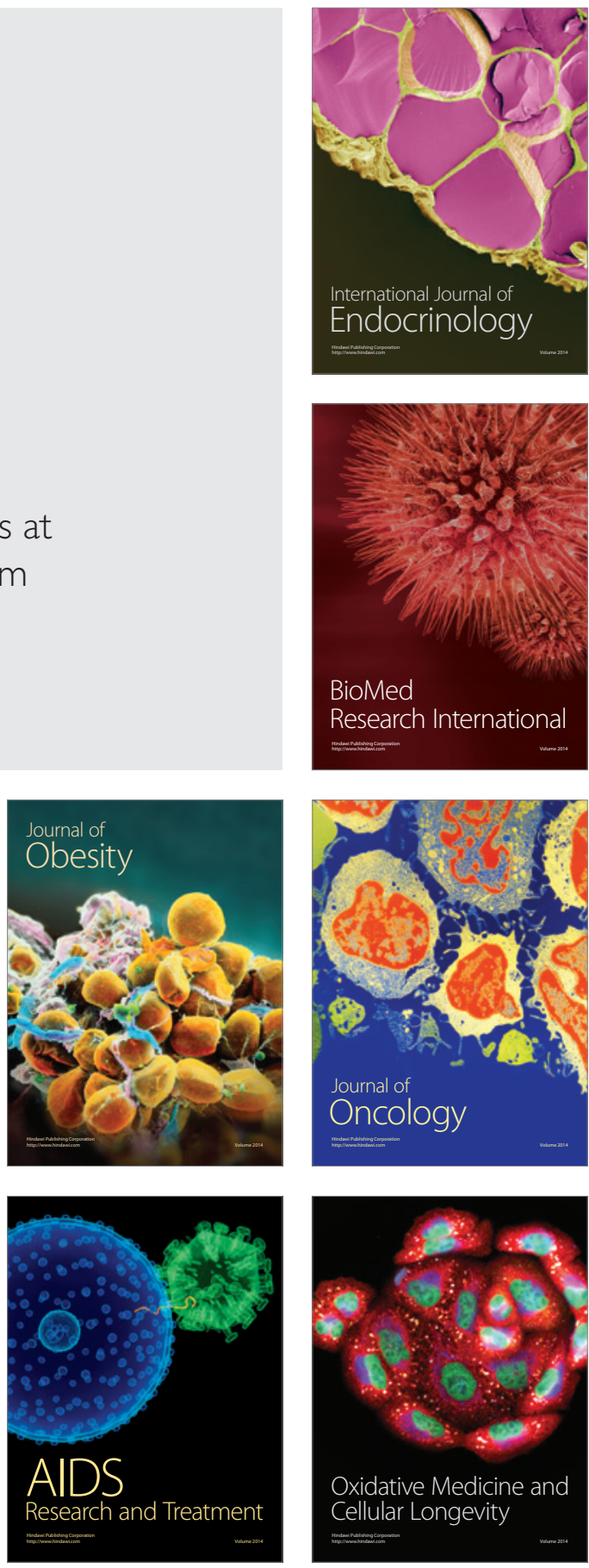